\title{
Future water quality monitoring - Adapting tools to deal with mixtures of pollutants in water resource management
}

Rolf Altenburger ${ }^{\mathrm{a} b \mathrm{~b}}$, Selim Ait-Aissa ${ }^{\mathrm{c}}$, Philipp Antczak ${ }^{\mathrm{d}}$, Thomas Backhaus ${ }^{\mathrm{e}}$, Damià Barcelóf, Francois Brion $^{\mathrm{c}}$, Wibke Busch ${ }^{\mathrm{a}}$, Kevin Chipman ${ }^{\mathrm{g}}$, Miren López de Alda ${ }^{\mathrm{f}}$, Gisela de Aragão Umbuzeiro ${ }^{\mathrm{h}}$, Beate I. Escher ${ }^{\mathrm{i}, \mathrm{a}}$, Francesco Falciani ${ }^{\mathrm{d}}$, Michael Faust ${ }^{\mathrm{j}}$, Andreas Focks ${ }^{\mathrm{k}}$, Klara Hilscheroval, Juliane Hollender ${ }^{\mathrm{m}}$, Henner Hollert ${ }^{\mathrm{b}}$, Felix Jägern , Annika Jahnke ${ }^{\mathrm{a}}$, Andreas Kortenkamp ${ }^{\mathrm{o}}$, Martin Krauss ${ }^{\mathrm{a}}$, Gregory F. Lemkine ${ }^{\mathrm{p}}$, John Munthe ${ }^{\mathrm{q}}$, Steffen Neumann ${ }^{\mathrm{r}}$, Emma L. Schymanski ${ }^{\mathrm{m}}$, Mark Scrimshaw ${ }^{0}$, Helmut Segner ${ }^{\mathrm{s}}$, Jaroslav Slobodnik ${ }^{\mathrm{t}}$, Foppe Smedes ${ }^{l}$, Kugathas Subramaniamº, Ivana Teodorovic ${ }^{u}$, Andrew J. Tindall ${ }^{\mathrm{p}}$, Knut Erik Tollefsen ${ }^{\mathrm{v}}$, Karl-Heinz Walz $^{\mathrm{w}}$, Tim D. Williams ${ }^{\mathrm{g}}$, Paul J. Van den Brink ${ }^{\mathrm{k}}$, Jos van Gils ${ }^{\mathrm{x}}$, Branislav Vranal, Xiaowei Zhang ${ }^{\mathrm{y}}$, Werner Brack $^{\mathrm{a}}$

${ }^{a}$ UFZ - Helmholtz Centre for Environmental Research, Permoserstr. 15, 04318 Leipzig, Germany

${ }^{\mathrm{b}}$ RWTH Aachen University, Aachen, Germany

c Institut National de l'Environnement Industriel et des Risques INERIS, BP2, 60550 Verneuil-en-Halatte, France

${ }^{\mathrm{d}}$ Centre for Computational Biology and Modelling, University of Liverpool, L69 7ZB, UK

e Department of Biological and Environmental Sciences, University of Gothenburg, Carl Skottbergs Gata 22b, 40530 Gothenburg, Sweden

${ }^{\mathrm{f}}$ Water and Soil Quality Research Group, Institute of Environmental Assessment and Water Research (IDAEACSIC), Jordi Girona 18-26, 08034 Barcelona, Spain

${ }^{g}$ School of Biosciences, The University of Birmingham, Birmingham B15 2TT, UK

${ }^{\mathrm{h}}$ University of Campinas, Limeira, Brazil

${ }^{i}$ National Research Centre for Environmental Toxicology (Entox), The University of Queensland, Brisbane, Australia

${ }^{\mathrm{j}}$ Faust \& Backhaus Environmental Consulting, Fahrenheitstr. 1, 28359 Bremen, Germany

${ }^{\mathrm{k}}$ Alterra, Wageningen University and Research Centre, P.O. Box 47, 6700 AA Wageningen, The Netherlands.

${ }^{1}$ Masaryk University - Research Centre for Toxic Compounds in the Environment (RECETOX), Masaryk

University, Kamenice 753/5, 62500 Brno, Czech Republic

${ }^{\mathrm{m}}$ Eawag, Swiss Federal Institute of Aquatic Science and Technology, 8600 Dübendorf, Switzerland

${ }^{n}$ Synchem UG \& Co. KG, Am Kies 2, 34587 Felsberg-Altenburg, Germany

${ }^{\circ}$ Brunel University, Institute of Environment, Health and Societies, Uxbridge, UB8 3PH, United Kingdom

${ }^{\mathrm{p}}$ WatchFrog, Bâtiment Genavenir 3, 1 rue Pierre Fontaine, 91000 Evry, France

${ }^{\mathrm{q}}$ IVL Swedish Environmental Research Institute, P.O. Box 53021, 40014 Göteborg, Sweden

${ }^{\mathrm{r}}$ Leibniz Institute of Plant Biochemistry, Weinberg 3, 06120 Halle

${ }^{\mathrm{s}}$ University of Bern, Centre for Fish and Wildlife Health, PO Box 8466, CH-3001 Bern, Switzerland

${ }^{\mathrm{t}}$ Environmental Institute, Okruzna 784/42, 97241 Kos, Slovak Republic

${ }^{\mathrm{u}}$ University of Novi Sad, Faculty of Sciences, Trg Dositeja Obradovića 321000 Novi Sad, Serbia

v Norwegian Institute for Water Research NIVA, , Gaustadalléen 21, N-0349 OSLO, Norway

${ }^{w}$ MAXX Mess- und Probenahmetechnik GmbH, Hechinger Straße 41, D-72414 Rangendingen

${ }^{x}$ Foundation Deltares, Potbus 177, 277 MH Delft, The Netherlands

${ }^{y}$ State Key Laboratory of Pollution Control \& Resource Reuse, School of the Environment; Collaborative Innovation Center for Regional Environmental Quality, Nanjing University, Nanjing, P. R. China, 210023

This document is the accepted manuscript version of the following article:

Ait-Aissa, S., Altenburger, R., Antczak, P., Backhaus, T., Barceló, D., Seiler, T. B., ... Brack, W. (2015). Future water quality monitoring - adapting tools to deal with mixtures of pollutants in water resource management. Science of the Total Environment, 512-513, 540-551. https://doi .org/10.1016/j.scitotenv.2014.12.057

This manuscript version is made available under the CC-BY-NC-ND 4.0

1icense http://creativecommons.org/1icenses/by-nc-nd/4.0/ 


\begin{abstract}
Environmental quality monitoring of water resources is challenged with providing the basis for safeguarding the environment against adverse biological effects of anthropogenic chemical contamination from diffuse and point sources. While current regulatory efforts focus on monitoring and assessing a few legacy chemicals, many more anthropogenic chemicals can be detected simultaneously in our aquatic resources. However, exposure to chemical mixtures does not necessarily translate into adverse biological effects nor clearly shows whether mitigation measures are needed. Thus, the question which mixtures are present and which have associated combined effects becomes central for defining adequate monitoring and assessment strategies. Here we describe the vision of the international, EU-funded project SOLUTIONS, where three routes are explored to link the occurrence of chemical mixtures at specific sites to the assessment of adverse biological combination effects. First of all, multiresidue target and non-target screening techniques covering a broader range of anticipated chemicals co-occurring in the environment are being developed. By improving sensitivity and detection limits for known bioactive compounds of concern, new analytical chemistry data for multiple components can be obtained and used to characterize priority mixtures. This information on chemical occurrence will be used to predict mixture toxicity and to derive combined effect estimates suitable for advancing environmental quality standards. Secondly, bioanalytical tools will be explored to provide aggregate bioactivity measures integrating all components that produce common (adverse) outcomes even for mixtures of varying compositions. The ambition is to provide comprehensive arrays of effect-based tools and traitbased field observations that link multiple chemical exposures to various environmental protection goals more directly and to provide improved in situ observations for impact assessment of mixtures. Thirdly, effect-directed analysis (EDA) will be applied to identify major drivers of mixture toxicity. Refinements of EDA include the use of statistical approaches with monitoring information for guidance of experimental EDA studies. These three approaches will be explored using case studies at the Danube and Rhine river basins as well as rivers of the Iberian Peninsula. The synthesis of findings will be organized to provide guidance for future solution-oriented environmental monitoring and explore more systematic ways to assess mixture exposures and combination effects in future water quality monitoring.
\end{abstract}


List of acronyms

AA - annual average

AOP - Adverse outcome pathways

BQE - Biological quality elements

CIS - Common European implementation strategy

DG SANCO -Directorate General for Health and Consumer Protection of the European

Commission

EDA - Effect-directed analysis

EQS - Environmental quality standards

EROD - Ethoxyresorufin-O-deethylase

EU - European Union

GC-MS/MS - Gas chromatography coupled with double mass spectrometry

GFP - Green fluorescent protein

GST - Glutathione sulfotransferases

HPCCC - High performance counter current chromatography

KE - Key event

LC-HRMS/MS - Liquid chromatograpy of high resolution coupled with double mass

spectrometry

MAC - Maximum allowed concentrations

MIE - Molecular initiating event

MoA - Mode of action

PAH - Polycyclic aromatic hydrocarbons

PNEC - Predicted no-effect concentration

RBSPs - River basin specific pollutants

TU - Toxic units

WFD - Water Framework Directive 


\section{Introduction}

The monitoring of freshwaters with the goal of safeguarding environmental water quality in Europe so far has focused on the evaluation of the ecological and chemical status of water bodies. For the ecological status biological and hydromorphological quality elements are considered, while the chemical status is judged based on consideration of a few selected compounds (EU Dir 2000/60, EU Dir 2013/39). The established techniques for the biological quality elements rely on phytoplankton, macrophytes, phytobenthos, benthic invertebrate, and fish fauna recordings (EU Dir 2000/60). These monitoring efforts are carried out on a wide scale and at regular intervals, such that the ecological status is the aggregate of occurrence and abundance information. The chemical status, on the other hand, is derived from information on analytically determined concentrations of priority pollutants in different compartments such as water, sediment and biota, which are compared against Environmental Quality Standards (EQS) (EU Dir 2008/105, CIS GD 27, 2011). Complementary efforts include emission monitoring, effluent testing for acute toxic effects, and risk management measures for specific products, such as buffer zones for pesticide application or product labelling for pharmaceuticals or consumer products.

Despite the enormous efforts, the picture that emerges regarding ecological and chemical status is still incomplete, fragmented, and with contradictory assessments of the situation. There is general consensus that the target of "good ecological status" defined in the Water Framework Directive (WFD) will not be reached for the majority of European water bodies within the anticipated timeframes (EEA, 2012). Among the causes for this failure the contribution of chemical contamination, however, remains unclear, although efforts to assess chemical monitoring results point to a contributory role of chemical contamination (Malaj et al. 2014). Overall, about 40\% of European water bodies (EC COM 673, 2012) still have an unknown chemical status as not even the monitoring of the EU-wide priority substances has been performed. From a management perspective the legacy compounds are of diminishing importance, due to decreasing use of these substances (many are regulated or banned) and the growing awareness that many other chemicals occur and may cause adverse effects in the aquatic environment. The occurrence of anthropogenic chemicals in the environment appears indeed to be widespread and the detection of mixtures of contaminants seems to be the rule rather than the exception (Kolpin et al. 2002, Loos et al. 2009). While elaborated hazard assessments leading to environmental quality standards are performed for priority pollutants, this is not the case for most other chemicals that have been recently detected. This is why these may be referred to as contaminants of emerging concern (EPA, http://water.epa.gov/scitech/cec/).

The European Commission became aware of the problem of chemical mixtures (Council Conclusions 2009), and in its communication on the combination effects of chemicals (EC COM 252, 2012) describes the challenges requiring scientific support. In principle, tools for analysing and assessing combined effects from defined mixtures have been well studied and documented over the past decades (e.g. Kortenkamp and Altenburger 2011) and suggestions about how component-based predictive environmental risk assessment may be performed are presented (e.g. Backhaus and Faust 2012). Thus, the existence of combined effects is a fact and the principal means of addressing them are known (EC 2011). The challenge now is to develop systematic ways of addressing chemical mixtures in environmental assessment (EC COM 252, 2012).

The EU-funded SOLUTIONS project (http://www.solutions-project.eu/) takes up this challenge for water quality assessment and monitoring by undertaking to improve monitoring strategies and combining them with modelling efforts based on pre-market data (Brack et al. 
2015). Here we outline our strategies for analysing and assessing chemical mixtures for water quality monitoring purposes. We intend to explore three options for identifying and developing systematic approaches to accommodate for contaminant mixtures in water quality assessment (Fig 1). Firstly, we test the hypothesis that it is possible to identify mixtures whose compositions are representative for specific sites or typical for specific sources and are thus amenable to component-based mixture assessment. Secondly, we elaborate means of identifying batteries of bioanalytical assays that allow comprehensive assessment of impact of mixtures on water quality. Finally, we combine effect-based and chemical analytical tools to probe causal links between mixture occurrence and combined effects and to support the identification of drivers of mixture toxicity.

Fig. 1: Challenges to deal with mixtures of pollutants in water quality monitoring and to provide management solutions

The major questions of combination effects of chemicals (EC COM 252, 2012) with regard to their impact on water quality assessment and the above mentioned strategies will be studied in the context of case studies at the river Danube (de Deckere et al 2012, Grund et al. 2011, Liska et al. 2008), the Rhine catchment (Hollender et al 2009, Ter Laak et al 2010) and for rivers of the Iberian Peninsula (Muñoz at al, 2009, Navarro-Ortega et al. 2012). Investigations will be based on existing data and experimental studies. Moreover, these case studies will be utilised to complement and jointly evaluate results from modelling and measurement-based approaches (Brack et al. 2015).

\section{Identification of priority mixtures}

The Scientific Committees of the Directorate General for Health and Consumer Protection (DG SANCO) have emphasised that 'in view of the almost infinite number of possible combinations of chemicals [...] focus on mixtures of potential concern is necessary' (EC 2011). A number of criteria were proposed for consideration, including co-occurrence at individual concentrations below but close to acceptable levels, indications for similar action, and the potential for toxicological interactions. Additional criteria, such as scale of exposure (EC COM 252, 2012), co-occurrence of transformation products or source attributions might be considered. In general, if bias towards known contaminants is to be reduced, this task requires on the one hand multi-residue target and non-target screening techniques to cover mixtures occurring in the environment more comprehensively. On the other hand, improvements leading to lower detection limits for known bioactive compounds are also needed as for some of the newly established water priority substances (Table 1) it is currently virtually impossible to analytically determine compounds at the very low EQS concentrations set for them in the WFD.

Table 1: $\quad$ Environmental Quality Standard (EQS), annual average (AA) and maximum allowable concentrations (MAC) set for the newly established WFD priority substances in inland and other surface waters* (EU Directive 2013/39/EU). Unit: $\mu \mathrm{g} / \mathrm{l}$, nomenclature as in the legal reference

It is therefore the goal of the SOLUTIONS project to improve chemical analytics both with respect to capabilities to screen for more compounds and to improve present detection limits. Subsequently, the data from case studies will be utilised to investigate the co-occurrence of components. To identify mixtures of priority, two data evaluation strategies will be pursued. 
Firstly, we will try to identify patterns of co-occurring compounds and correlate them to site characteristics, land use or specific contamination sources. Secondly, to support the assessment of detected mixtures, toxicity data gaps will be filled through modelling and subsequent hazard quotient formulation. The results will be used in component-based mixture toxicity extrapolations to identify mixtures of potential toxicological concern (Price et al. 2011).

The significant analytical gaps regarding the detection limits of compounds with very low PNECs or EQS (Table 1) in environmental media and/or biota require novel concepts in the sampling and clean-up of samples. With a given sensitivity of chemical analytical techniques, detection limits can be improved by accumulating and concentrating compounds from larger volumes of water, e.g. either by passive sampling or by large volume solid phase extraction. Table 2 lists the approaches that are pursued to this end and summarizes the existing experience within the SOLUTIONS consortium.

The number of analytical methods developed for targeted determination of emerging contaminants has experienced rapid growth over recent years and continues to increase which has led to the discovery of new environmental contaminants, metabolites and transformation products. Major gaps remain with respect to the identification and elucidation of the structure of known and unknown components of complex environmental mixtures potentially composed of tens of thousands of components. Two recent studies (Malaj et al. 2014, Moschet et al. 2014) demonstrated that more comprehensive analytical compound screening may substantially alter the assessment of surface water quality. In the study of Moschet et al. (2014), five Swiss riverine catchments were sampled during spring and analysed for the occurrence of some 250 components, mainly pesticides and biocides. AA-EQS exceedances for 19 compounds occurred in $70 \%$ of the water samples. This observation would have escaped attention when restricting the assessment to priority components only. Malaj et al. (2014) provide evidence that compounds occurring in European freshwaters even for routinely monitored chemicals such as $\gamma$-hexachlorocyclohexane, atrazine, cyanide, chlorpyrifos, chlorfenvinfos, or diuron at their detected concentrations may be close to hazardous concentrations at many sites. A second finding was that the outcome of risk assessment critically depends on the number of compounds analysed: often, apparently low environmental risk associates with a limited number of monitored chemicals. After these proof-of-principle investigations, subsequent steps should therefore address the question of how to assess the totality of hazardous contamination in a reliable way while at the same time keeping efforts at a realistic level. To address this issue a focus on priority mixtures that might be derived from chemical analytical information is a promising approach. Priority mixtures identification based on the analytical data is, in our perspective, not limited to sets of defined chemicals at specified concentrations but rather an analysis of patterns is needed as described above.

SOLUTIONS looks for answers regarding better coverage of detectable and unidentified compounds by establishing non-target screening workflows and a set of interacting compound identification tools which integrate GC-MS/MS and LC-HRMS/MS technology with computer tools for retention, fragmentation, hydrogen-deuterium exchange and toxicity prediction and database for mass spectra. More details concerning the roads taken are summarised in Table 2.

Table 2: $\quad$ Chemical analytical problems addressed in the SOLUTIONS project to support priority mixture identificatio

Once we obtain more comprehensive data on the occurrence of multiple chemicals in 
freshwaters by means of targeted, multi-residue, and screening chemical analytical efforts, the subsequent issue will be to find out whether mixture patterns can be elucidated. In order to identify potentially repetitive mixture patterns, analytical data for detected compounds could be subjected to data clustering. An exemplary effort is illustrated in Figure 2.

Here, out of 396 organic compounds that were analysed and quantified in water samples from five small rivers of the Rhine catchment (Moschet et al. 2014), 141 chemicals were found to occur above their detection limits in at least one of the rivers. The data was hierarchically clustered (distance method = "Euclidian", clustering method = "Ward") according to the site of occurrence and the detected concentrations. At this coarse level, groups of chemicals with high, moderate and low concentrations can be determined and site-specific occurrences become obvious. Using this approach for comparing more sites including additional chemical, toxicological (e.g. hazard ratios), or site-specific information may be advanced to allow characteristic toxicological signatures to be correlated with the different human activities such as the cultivation of grains, orchards or meadows as opposed to urban, domestic, or industrial influences. Moreover, the scale of occurrence of mixtures and archetypical versus river basinspecific pollutants may be derived.

Fig 2: $\quad$ Heatmap of concentrations for 141 chemicals reported in Moschet et al. (2014) in five rivers, clustered to identify occurring mixture patterns. MDL=minimum detection limit

Efforts such as those from Malaj et al. (2014) and Moschet et al. (2014) not only provide wider coverage of priority pollutants and currently used pesticides than previously available, but also demonstrate that the detectable concentrations may raise concern for unwanted biological effects. To study the significance, temporal and spatial scale of occurring concentrations, complementary comparison with toxicity information for the detected compounds should help. Subsequently, any concentration-response-relationship information can feed into component-based mixture toxicity modelling approaches (Altenburger et al. 2004, Altenburger and Greco 2009) to derive estimates of resulting combined effect. The results of these combined effect estimates may in turn prove to be suitable for the development of a novel perspective for identification of river basin-specific pollutants and for advanced EQS settings for priority mixtures.

\section{Impact of mixtures}

Chemical monitoring of water quality accounts for quantitative assessments of the occurrence and fate of known contaminants in water bodies and thus facilitates the management and remediation of defined compounds. The ultimate goal of water quality management under the WFD, however, lies in the provision of good ecological and chemical status. Thus, analytically undetected but toxicologically relevant compounds, transformation products and mixture effects may be overlooked in an approach that is purely based on chemical analytical measurements. It is suggested that bioanalytical tools can improve the environmental impact assessments (CMEP 2014, Escher and Leusch. 2012, Malaj et al. 2014). A second goal in SOLUTIONS, therefore, is to advance and apply bioanalytical methods to see whether improved impact assessment of mixtures is within reach. The simultaneous exposure of organisms to different compounds may not necessarily mean that combined effects are evoked at detectable levels (Altenburger et al. 2004). This may be due to individual components acting differently and it may be due to the relation between the dose-dependency of components and the concentrations found in the mixtures which may not give rise to 
detectable contributions (EC 2011). A way forward for mixture impact assessment for field situations may be seen in devising bioanalytical tools that are tailored for specific mixture assessment objectives.

Bioanalytical tools are defined here as assays which capture key events (KE) of biological reactions following experimentally controlled or observed chemical exposure and molecular initiating events (MIE) in an organism, detected at the level of the cell, organism, population or community and possibly leading to adverse outcomes. Moreover, these tools can inform us about the existing toxic pressure for biological systems if employed in situ. The first large scale attempts have recently been made to address the use of various bioassays for mixture impact analysis of surface waters (Escher et al. 2014, Carvalho et al. 2014). Subsequently to demonstrating that effects of mixtures seem to be relevant in various environmental settings, different management perspectives can be distinguished. The management problem may need (i) diagnostics, i.e., identifying the biological receptor that is affected by mixture exposure; (ii) forensics, i.e., elucidating the causes of an emerging adverse effect and their responsible source; or (iii) status assessments, i.e., allocating the contribution of chemicals to an impaired ecological status and delivering a prognosis for the development of the water quality.

The underlying conceptual thinking in the SOLUTIONS project for benchmarking the studied bioanalytical tools with respect to their contributions for the different mixture impact questions will be based on a modified version of the concept of adverse outcome pathways (AOPs)(Ankley et al 2010, OECD 2013) as illustrated in Fig 3. In distinction to the AOP concept we here deal with mixtures, where it is conceived that no longer individual molecular initiating events but rather measures of common adverse outcome are required to capture potential mixture impacts (EFSA 2013). We thus define key events as those observations that integrate several potential MIEs. This would comprise simultaneous observation of activation or inhibition of various nuclear receptors but also detecting alterations of biotransformation which under mixture exposure can provide indication for unexpected combined effects. In the AOP at the next level of biological complexity cellular stress responses and subsequently organisms fitness measures are observed.

Effect-based tools summarise all the various cell- or organism-based bioassays that typically are performed in the lab to characterize environmental samples. Effect-based tools with response detection on the molecular, subcellular or cellular levels are believed to aggregate the combined effects of similar bioactive components for the specific responses they are designed to capture. For diagnostic or forensic tasks arrays of tools will have to be designed to cover different biological effect qualities, while for surveillance tasks where a defined receptor is to be protected, individual tools might provide effective impact detectors.

Effect-based tools that detect apical organism responses are easily related to toxicologically consented adverse effects and thus lend themselves to applications in chemical environmental hazard assessment. Mixture impact assessment is currently well capable of assessing the combined toxicity of similar and dissimilar acting components at the organism level (Altenburger and Greco 2009), whereas understanding the translation of mixture responses observed in molecular and cellular assays and more apical and regulatory-relevant assays remains a formidable research challenge (Altenburger et al. 2012). Therefore, by linking the responses from the different organisational levels through the integrated use of bioassays representing the molecular, cellular, organism and population level we aim to improve our understanding of potential biases in the existing effect detection tools.

Finally, ecological tools are employed to bridge toxicological effect findings as understood for individual organisms and chemical mixtures from the effect-based tools, to field observations of compromised ecological structure and function. Two perspectives are pursued here, on the one hand for selected effects, such as exposure stimulated metabolism we perform in situ 
studies on feral fish ( Brinkmann et al. 2013, Boettcher et al. 2010) (table 3) while on the other hand we will deploy trait-based approaches to investigate community-level effects of chemical contaminants. Trait-based approaches are used increasingly to derive correlations between the occurrence of species traits and exposure to (mixtures of) chemicals, but also to distinguish between chemical stress effects and impact of other major pressures, e.g. hydromorphological alterations or eutrophication. If mode of action (MoA)-specific species traits can be identified, biomonitoring data could be used as a marker for chemical stress at the aggregating MoA level. This assessment can also be used to identify the chemicals likely to pose the highest ecological risks (Van den Brink et al., 2013).

Fig 3: Conceptual framework for bioanalytical tools illustrating their place in an adverse outcome pathway network elucidated by mixture exposure and indicating the potential roles of bioanalytical tools in mixture impact assessment

A variety of bioanalytical tools will be explored in this project (Table 3) for their capabilities to aggregate mixture effects of chemicals irrespective of the presence of possibly unknown chemicals, or variability in the mixture composition. The list is not comprehensive but comprises (i) in vitro nuclear- and cell-reporter assays that indicate intracellular presence of contaminants or detect specific receptor- or aggregated stress responses, (ii) standard toxicological organism-based bioassays that detect apical responses in fish, daphnia and algae and directly relate to established biological quality elements (BQE), and (iii) ecology-oriented bioindicators using biomarker responses in individuals or community function (pollutioninduced community tolerance), or trait-based composition information. The bioanalytical tools to be applied in the SOLUTIONS project are further specified in Table 3 regarding their properties, perspective and the existing experience.

Table 3: Bioanalytical tools used in the SOLUTIONS project to improve the impact assessment of mixtures for diagnostic, forensic and ecological quality purposes

Bioanalytical tools in their totality and in future arrays could thus help determine the impact of mixtures with respect to distinct water quality management questions. Moreover, if proven workable, this approach could possibly link multiple chemical exposure assessment directly to specific environmental protection goals.

\section{Identification of mixture toxicity drivers}

Despite the presence of mixtures of multiple compounds in environmental media and samples, theoretical considerations and experimental findings suggest that the overall risk may be driven by only a few mixture components (Altenburger et al. 2004, Backhaus and Karlsson 2014, Price et al. 2012). The European Commission considers the development of methodologies for the identification of such drivers of mixture toxicity a research priority (EC COM 252, 2012). One of the major challenges in the assessment of complex environmental mixtures therefore is the identification of those chemicals that contribute significantly to observed effects. Furthermore, routinely detected chemicals often cannot explain observed biological responses (e.g., Escher et al. 2013) which points to a mismatch between these assessment approaches. This mismatch may be resolved through joint efforts from both disciplines for the different lines of evidence, e.g., by linking chemical monitoring and biological effect and monitoring data by traits-based or effect-directed approaches. 
Effect-directed analysis (EDA) may help to identify novel and unexpected compounds that may cause adverse effects on biota and human health (Brack et al. 2008). The principle of EDA is to reduce natural samples to less complex mixtures or individual compounds by bioassay-directed fractionation of environmental samples so that relevant toxicants can be isolated and identified. The approach has been demonstrated as useful in several instances (Brack 2011, Houtman et al. 2007, Thomas et al. 2009) and will be advanced and applied on water, sediments and fish from selected sites in the river basins of Danube, Rhine, and beyond. Current limitations of EDA due to laborious and time-consuming procedures will be addressed by SOLUTIONS. This includes specific investigations on the application of EDA for monitoring, structure elucidation of unknown polar compounds, increasing the number of bioanalytical endpoints, and the application to food chain accumulation and thus secondary poisoning.

The approach pursued is illustrated in Figure 4. SOLUTIONS will develop a tiered protocol to identify river basin-specific pollutants that can be considered drivers of mixture toxicity. To date, the monitoring of contaminants according to WFD is restricted to chemical analytical monitoring of individual chemicals. In the first tier this information can be used for the establishment of MoA that are known to be relevant in specific water bodies or river basins supporting a MoA- or BQE-specific default approach e.g. based on the summation of toxic units of the components (Backhaus and Faust 2012). This approach already goes beyond the current WFD approach and provides a first set of chemical target screening-based candidate drivers. The MoA information also helps to complement chemical monitoring with multiendpoint (eco)toxicological screening and allows for the identification of mismatches between candidate drivers and multiple biological effects. If unexplained biological effects occur, WFD-like chemical target monitoring is extended in tier 2 by multi-target and non-target screening in order to achieve a more comprehensive picture of contamination patterns. In combination with (eco)toxicological screening, this provides the basis for a novel approach called virtual EDA to identify chemical signals that are correlated with effects from background signals. Virtual EDA has been suggested as a term by Eide et al. (2002) and has been recently evaluated in a proof of concept study for the characterisation of chemicals responsible for mutagenic effects in a river impacted by an industrial effluent (Hug et al., in prep.). The approach reduces the complexity of mixture components through the use of multivariate statistics and pattern recognition methods on samples for several sites as a virtual decomposing approach which should direct the focus of subsequent more elaborated identification efforts to a subset of sites. SOLUTIONS will test this approach in case studies on contaminated samples from the Danube and Rhine river basins. Still unexplained mixture effects will be addressed through higher tier EDA studies (tier 3) as a site-specific approach, which will also be used to validate the results of virtual EDA at specific sites.

The identification of unknown compounds using mass spectrometry data remains a major bottleneck in many disciplines (Creek et al. 2014, Scheubert et al. 2013) and often hinders the successful completion of EDA studies (Schymanski et al. 2009). Efforts in SOLUTIONS will therefore focus on the development of methods for generating and pre-selecting toxicant candidate structures from the given analytical and effect information as indicated in Table 2. The structure elucidation approaches also include efforts for the integration of prediction of transformation, toxicity, physico-chemical properties, MS fragmentation and chromatographic retention.

Fig 4: $\quad$ Principles of a tiered effect-directed analysis (EDA)

The diagnostic power of higher tier EDA will be addressed through efforts to adapt assays for 
specific key events (see Table 3) as effect detectors for EDA. An array of screening assays potentially covering multiple species, MoAs and adverse effects (see Table 3 for details) will be deployed in the EDA approach.

Moreover, food chain accumulation will be approached exemplarily for fish tissue to investigate bioaccumulation and secondary poisoning through feed and food contaminated with complex mixtures of pollutants. Performing EDA on such tissue will aim to detect and identify bioavailable and bioaccumulative toxicants (Houtman et al. 2004), including metabolites formed in the organisms (Jeon et al. 2013).

\section{Perspectives for solution-oriented mixture assessment}

A central deliverable of the SOLUTIONS project is to generate guidance for the three mixture assessment challenges identified by the European Commission (EC COM 252, 2012), namely (i) the characterisation of priority mixtures, (ii) mixture impact assessment, and (iii) the identification of toxicity drivers. The need to tailor environmental monitoring tools towards contamination diagnosis in complex environmental matrices, however, is acknowledged on a worldwide scale. E.g. Environment Canada (2014) suggests guidance to use effect-based methods for aquatic effects monitoring from pulp and paper production. In Australia, where the water cycle is an issue with the perspective of reuse for humans, strict standards for a larger number of potential hazardous compounds have been formulated and it is suggested to link chemical and bioanalytical tools for water quality monitoring (Tang et al. 2014).

Thus the goals set out here should be of a wider interest. To achieve them we will provide documentation of the chemical analytical and bioanalytical tools and specify the approaches for the different needs in water quality monitoring and assessment. The various problems in current water quality management call for tailored approaches, which could provide solutionoriented mixture assessments. For instance, the identification of river basin-specific priority groups of pollutants (RBSPs) needs to be improved for river basin management plans, while risk assessment for unwanted effects calls for a more prominent role of bioanalytical tools. Mixture assessment is essential for water quality management, given the complexity of typical pollution scenarios. The tools that will be provided by the SOLUTIONS project shallfacilitate achieving this aim. The task is to operationalise the required mixture assessment, i.e. to tailor the available tools for the specific tasks laid out above. The SOLUTIONS project as a whole sets out to not only provide advanced methodologies for water quality monitoring, but also to deliver suggestions for testing requirements and data needs for carrying out mixture risk assessment and management in the context of the WFD. The last step will be performed in collaboration with the modelling, case studies and conceptual framework activities (Brack et al. 2014).

The NORMAN network (http://www.norman-network.net/) has recently proposed a novel risk assessment-based approach for prioritisation of water pollutants for improving water monitoring (Dulio and von der Ohe 2013, Brack et al. 2012). It suggests a strategy to cope with scarce data for individual compounds and to account for different management action categories. The scheme, however, remains limited to individual compound assessments. The tools developed and the data generated within the SOLUTIONS case studies may be used to amend such prioritisation schemes to address mixtures of contaminants of emerging concern and their impacts explicitly.

The larger vision of future water resource management and the contributions that can be anticipated, bears yet another level of perspectives. It is widely acknowledged that European water bodies are affected by multiple types of stress, such as water scarcity, morphological changes, and pollution. Addressing the joint effects from such multiple stressors in 
management is limited by the currently available knowledge (Hering et al. 2014, NavarroOrtega et al. 2014). Two international EU-funded projects, MARS (Hering et al. 2014) and GLOBAQUA (Navarro-Ortega et al. 2014), are addressing several primary and secondary stressors such as water flow extremes, thermal extremes, eutrophication, and impaired habitat morphology. The efforts in SOLUTIONS are clearly complementary and issues are easily identified where joint efforts could improve our mechanistic understanding of interactions between say low water flow and the impact of pollution. Also, as risk assessment, WFD status assessment and the understanding of ecosystem services follow different but related frameworks (Hering et al. 2014), we could gain improved coherence by providing better understanding of each of the frameworks. Finally, we could learn to consistently address scaling issues from the water body through the river basin up to the continental scale.

The revision of the WFD in 2019, the ongoing discussion on a common European implementation strategy (CIS), as well as the cycle of readjustments and refinements of river basin management planning (RBMPs) will be the outreach targets for our research activities. Timely provision of validated chemical analytical or bioanalytical tools, improved knowledge and useful decision support instruments will be vital for translating the various ideas into better practises. Moreover, an improved understanding of how mixture assessment may be performed could generate incentives for more coherent approaches in water resource management by providing the means for cross-compliance measures in environmental regulation.

\section{Acknowledgments}

The SOLUTIONS Project is supported by the Seventh Framework Programme (FP7-ENV-2013) of the European Union under grant agreement no. 603437.

\section{References}

Altenburger R, Walter $\mathrm{H}$, Grote $\mathrm{M}$. What contributes to the combined effect of a complex mixture? Environ Sci Technol 2004;38:6353 - 6362.

Altenburger R, Greco WR. Extrapolation concepts for dealing with multiple contamination in environmental risk assessment. Integrated Environmental Assessment and Management 2009;5:62 68.

Altenburger R, Scholz S, Schmitt-Jansen M, Busch W, Escher BI. Mixture toxicity revisited from a toxicogenomic perspective. Environ Sci Technol 2012;46:2508-2522.

Ankley GT, Bennett RS, Erickson RJ, Hoff DJ, Hornung MW, et al. Adverse outcome pathways: A conceptual framework to support ecotoxicology research and risk assessment. Environ Toxicol Chem 2010;29:730-741.

Backhaus T, Faust M. Predictive environmental risk assessment of chemical mixtures: a conceptual framework. Environ Sci Technol 2012;46:2564-2573.

Backhaus T, Karlsson M. Screening level mixture risk assessment of pharmaceuticals in STP effluents. Water Res 2014;49:157-65.

Blanck H. A critical review of procedures and approaches used for assessing pollution-induced community tolerance (PICT) in biotic communities. Human and Ecological Risk Assessment 2002;8:1003-1034.

Boettcher M, Grund S, Keiter S, Kosmehl T, Reifferscheid G, Seitz N, Rocha PS, Hollert H, Braunbeck T. Comparison of in vitro and in situ genotoxicity in the Danube River by means of the comet assay and the micronucleus test. Mutation Research - Genetic Toxicology and Environmental Mutagenesis 2010;700:11-17.

Brack et al. SOLUTIONS for present and future emerging pollutants in land and water resources 
management. Sci Tot Environ, 2015;503-504:22-31

Brack W, Schmitt-Jansen M, Machala M, Brix R, Barcelo D, et al. How to confirm identified toxicants in effect-directed analysis. Anal Bioanal Chem 2008;390:1959-1973.

Brack W. Effect-Directed Analysis of Complex Environmental Contamination: Springer, Berlin. 2011.

Brack W, Dulio V, Slobodnik J. The NORMAN Network and its activities on emerging environmental substances with a focus on effect-directed analysis of complex environmental contamination.

Environmental Sciences Europe, 2012;24:29.

Brinkmann M, Hudjetz S, Kammann U, Hennig M, Kuckelkorn J, Chinoraks M, Cofalla C, Wiseman S, Giesy JP, Schäffer A, Hecker M, Wölz J, Schüttrumpf H, Hollert H. How flood events affect rainbow trout: Evidence of a biomarker cascade in rainbow trout after exposure to PAH contaminated sediment suspensions. Aquatic Toxicology 2013;128-129:13-24.

Brion F, Le Page Y, Piccini B, Cardoso O, Tong S-K, Chung B-C, Kah O. Screening estrogenic activities of chemicals or mixtures in vivo using transgenic (cyp19a1b-GFP) zebrafish embryos. PLoS One 2012;7(5): p. e36069.

Büttner A, Busch W, Klüver N, Giannis A, Scholz S. Transcriptional responses of zebrafish embryos exposed to potential sonic hedgehog pathway interfering compounds deviate from expression profiles of cyclopamine. Reproductive Toxicology 2012;33:254-263.

Carvalho RN, et al. Mixtures of chemical pollutants at European legislation safety concentrations: How safe are they? Toxicol Sci 2014;141:218-233.

CIS GD 27. Common Implementation Strategy for the Water Framework Directive (2000/60/EC). Guidance Document No. 27, 2011.

CMEP. WFD CIS subgroup Chemical Monitoring and Emerging Pollutants. Technical report on aquatic effect-based monitoring tools, 2014.

Council conclusions Combination effects of chemicals - Council conclusions 17820/09. Adopted by the Council on 22 December 2009 (Available online at:

http://register.consilium.europa.eu/pdf/en/09/st17/st17820.en09.pdf).

Creek DJ, Dunn WB, Fiehn O, Griffin JL, Hall RD, Lei Z, Mistrik R, Neumann S, Schymanski EL, Sumner LW, Trengove R, Wolfender J-L, Metabolite Identification: are you sure? And how do you peers gauge your confidence, Metabolomics 2014;10:350-353.

Creusot N, Tapie N, Piccini B, Balaguer P, Porcher JM, Budzinski H, Aït-Aïssa S. Distribution of steroid- and dioxin-like activities between sediments, POCIS and SPMD in a French river subject to mixed pressures. Environ Sci Pollut Res 2013a;20:2784-2794.

Creusot N, Budzinski H, Balaguer P, Kinani S, Porcher JM, Aït-Aïssa S. Effect-directed analysis of endocrine disrupting compounds in multi-contaminated sediment: identification of novel ligands of estrogen and pregnane X receptors. Anal. Bioanal. Chem 2013b;405:2553-2566.

de Deckere E, Brack W, Ballaer B, von der Ohe PC. Identifying key stressors in Danube, Elbe, Llobregat and Scheldt based on regular monitoring data. River Sys 2012;20:1-2.

Dulio V., von der Ohe P.C. (eds). NORMAN Prioritisation framework for emerging substances. NORMAN Association, ISBN : 978-2-9545254-0-2. 2013.

EC COM 252. The combination effects of chemicals - Chemical mixtures. Communication from the Commission to the Council, COM(2012) 252 final.

EC COM 673. A Blueprint to Safeguard Europe's Water Resources, Communication from the Commission to the European Parliament, the Council, the European Economic and Social Committee and the Committee of the Regions, $\operatorname{COM}(2012) 673$ final.

EC (European Commission - Directorate-General for Health \& Consumers - Scientific Committee on Health and Environmental Risks (SCHER), Scientific Committee on Emerging and Newly Identified Health Risks (SCENIHR) Scientific Committee on Consumer Safety (SCCS)). Toxicity and Assessment of Chemical Mixtures (Final approved opinion). 2011.

EEA European Environment Agency. European Waters - assessment of status and pressures. EEA, http://www.eea.europa.eu/themes/water/publications-2012, 2012.

EFSA (European Food Safety Authority) Panel on Plant Protection Products and their Residues (PPR). 
Scientific Opinion on the relevance of dissimilar mode of action and its appropriate application for cumulative risk assessment of pesticides residues in food. EFSA Journal 2013;11(12):3472, 40 pp. doi:10.2903/j.efsa.2013.3472.

Eide I, Neverdal G, Thorvaldsen B, Grung B, Kvalheim OM. Toxicological evaluation of complex mixtures by pattern recognition: correlating chemical fingerprints to mutagenicity. Environ Health Perspect 2002;110:985.

Environment Canada.2010 Pulp and paper environmental effects monitoring (EEM) technical guidance document. 2014.

EPA, http://water.epa.gov/scitech/cec/

Escher B, Leusch F. Bioanalytical tools in water quality assessment. IWA Publishing, London, UK. 2012.

Escher BI, Dutt M, Maylin E, Tang JYM, Toze S, Wolf CR, Lang, M. Water quality assessment using the AREc32 reporter gene assay indicative of the oxidative stress response pathway. Journal of Environmental Monitoring 2012;14:2877-2885.

Escher BI, van Daele C, Dutt M, Tang JY-M, Altenburger R. Most Oxidative Stress Response In Water Samples Comes From Unknown Chemicals: The Need For Effect-Based Water Quality Trigger Values. Environ Sci Technol 2013;47:7002-7011.

Escher BI, Allinson M, Altenburger R, Bain PA, Balaguer P, Busch W, Crago J, Denslow ND, Dopp E, Hilscherova K, Humpage AR, Kumar A, Grimaldi M, Jayasinghe BS, Jarosova B, Jia A, Makarov S, Maruya KA, Medvedev A, Mehinto AC, Mendez JE, Poulsen A, Prochazka E, Richard J, Schifferli A, Schlenk D, Scholz S, Shiraishi F, Snyder S, Su G, Tang JYM, van der Burg B, van der Linden SC, Werner I, Westerheide SD, Wong CKC, Yang M, Yeung BHY, Zhang X, Leusch FDL. Benchmarking organic micropollutants in wastewater, recycled water and drinking water with in vitro bioassays. Environ Sci Technol 2014;48:1940-1956.

EU Dir. 2000/60. Directive of the European Parliament and of the Council of October 200 establishing a framework for Community action in the field of water policy. Official Journal of the European Union 2000, L327/1, 22.12.2000.

EU Dir. 2013/39. Directive of the European Parliament and of the Council amending Directives 2000/60/EC and 2008/105/EC as regards priority substances in the field of water policy. Official Journal of the European Union 2013 L226/1, 24.8.2013.

EU Dir. 2008/105. Directive of the European Parliament and of the Council of 16 December 2008 on environmental quality standards in the field of water policy, amending and subsequently repealing Council Directives 82/176/EEC, 83/513/EEC, 84/156/EEC, 84/491/EEC, 86/280/EEC and amending Directive 2000/60/EC of the European Parliament and of the Council. Official Journal of the European Union 2008 L348/84, 24.12.2008.

Fetter E, Krauss M, Brion F, Kah O, Scholz S, Brack W. Effect-directed analysis for estrogenic compounds in a fluvial sediment sample using transgenic cyp19a1b-GFP zebrafish embryos. Aquat Toxicol. 2014;154:221-9.

Fini JB, Le Mevel S, Turque N, Palmier K, Zalko D, Cravedi JP, Demeneix BA. An in vivo multiwellbased fluorescent screen for monitoring vertebrate thyroid hormone disruption. Environ Sci Technol 2007;41:5908-14.

Gerlich M and Neumann, S. MetFusion: integration of compound identification strategies; J. Mass Spectrom. 2013;48:291-298.

Grund S, Higley E, Schoenenberger R, Suter MJF, Giesy JP, Braunbeck T, Hecker M, Hollert H. The endocrine disrupting potential of sediments from the Upper Danube River (Germany) as revealed by in vitro bioassays and chemical analysis. Environmental Science and Pollution Research 2011;18:446460.

Hering D, et al. Managing aquatic ecosystems and water resouces under multiple stress - An introduction to the MARS project. Sci Tot Environ 2014;503-504:10-21.

Hollender J, Zimmermann SG, Koepke S, Krauss M, McArdell CS, et al. Elimination of organic micropollutants in a municipal wastewater treatment plant upgraded with a full-scale post-ozonation followed by sand filtration. Environ Sci Technol 2009;43:7862-7869. 
Holth TF, Tollefsen KE. Acetylcholine esterase inhibitors in effluents from oil production platforms in the North Sea. Aquatic Toxicology 2012;112-113:92- 98.

Houtman CJ, Van Oostveen AM, Brouwer A, Lamoree MH, Legler J. Identification of estrogenic compounds in fish bile using bioassay-directed fractionation. Environ Sci Technol 2004;38:64156423.

Houtman CJ, Booij P, van der Valk KM, van Bodegom PM, van den Ende F, Gerritsen AA, Lamoree $\mathrm{MH}$, Legler J, Brouwer A. Biomonitoring of estrogenic exposure and identification of responsible compounds in bream from Dutch surface waters. Environ Toxicol Chem 2007;26:898-907.

Huerta B, Jakimska A, Gros M, Rodríguez-Mozaz S, Barceló D. Analysis of multi-class pharmaceuticals in fish tissues by ultra-high-performance liquid chromatography tandem mass spectrometry. Journal of Chromatography A 2013;1288:63-72.

Hug C, Ulrich N, Schulze T, Brack W, Krauss, M. Identification of novel micropollutants in wastewater by a combination of suspect and nontarget screening, Environmental Pollution 2014;184:25-32.

Hug in prep.

Huntscha S, Hofstetter, Schymanski E, Spahr S, Hollender J. Biotransformation of benzotriazoles: insights from transformation product identification and compound-specific isotope analysis, Environ Sci Technol 2014;48:4435-4443.

Ignatova S, Hewitson P, Mathews B, Sutherland I. Evaluation of dual flow counter-current chromatography and intermittent counter-current extraction, Journal of Chromatography A 2011;1218:6102- 6106.

Jalova V, Jarosova B, Blaha L, Giesy JP, Ocelka T, Grabic R, Jurcikova J, Vrana B, Hilscherova K. Estrogen-, androgen- and aryl hydrocarbon receptor mediated activities in passive and composite samples from municipal waste and surface waters. Environment International 2013;59:372-383.

Jahnke A, Mayer P, Broman D, McLachlan MS. Possibilities and limitations of equilibrium sampling using polydimethylsiloxane in fish tissue. Chemosphere 2009;77:764-770.

Jahnke A, Mayer P, McLachlan MS, Wickström H, Gilbert D, MacLeod M. Silicone passive equilibrium samplers as 'chemometers' in eels and sediments of a Swedish lake. Environ Sci.: Processes Impacts 2014;16:464-472.

Jeon J, Kurth D, Hollender J. Biotransformation pathways of biocides and pharmaceuticals in freshwater crustaceans based on structure elucidation of metabolites using high resolution mass spectrometry, Chem Res Toxicol 2013;266:313-324.

Kammann U, Brinkmann M, Freese M, Pohlmann JD, Stoffels S, Hollert H, Hanel R. PAH metabolites, GST and EROD in European eel (Anguilla anguilla) as possible indicators for eel habitat quality in German rivers. Environmental science and pollution research international 2014;21:251930 .

Klüver N, Yang L, Busch W, Scheffler K, Renner P, et al. Transcriptional Response of Zebrafish Embryos Exposed to Neurotoxic Compounds Reveals a Muscle Activity Dependent hspb11 Expression. PLoS One 2011;6: e29063.

Knight AW, Little S, Houck K, Dix D, Judson R, Richard A, McCarroll N, Akerman G, Yang CH, Birrell L, Walmsley RM. Evaluation of high-throughput genotoxicity assays used in profiling the US EPA ToxCast (TM) chemicals. Regulatory Toxicology and Pharmacology 2009;55:188-199.

Kolpin DW et al. Pharmaceuticals, hormones, and other organic wastewater contaminants in U.S. streas. 1999-2000: a national reconnaissance. Environ Sci Technol 2002;36:1202-1211.

Kortenkamp A, Altenburger R. Toxicity from combined exposure to chemicals. In: van Gestel, CAM, Jonker MJ, Kammenga JE. (eds.). Mixture toxicity: linking approaches from ecotoxicology and human toxicology. CRC press, Boca Raton, p. 67 - 85. 2011.

Krauss M, Singer H, Hollender J. LC-high resolution MS in environmental analysis: from target screening to the identification of unknowns. Anal Bioanal Chem 2010;397:943-951.

Kugathas S, Sumpter JP. Synthethic glucocorticoids in the environment: First results on their potential impacts on fish. Environ Sci Technol 2011;45:2377-2383. 
Kurauchi K, Nakaguchi Y, Tsutsumi M, Hori H, Kurihara R, Hashimoto S, Ohnuma R, Yamamoto Y, Matsuoka S, Kawai S, Hirata T, Kinoshita M. In vivo visual reporter system for detection of estrogenlike substances by transgenic medaka. Environ Sci Technol 2005;39:2762-8.

Liska I, Slobodnik J, Wagner F. Joint Danube Survey 2, Final Scientific Report. International Commission for the Protection of the Danube River. 2008.

Lohmann R, Booij K, Smedes F, Vrana B. Use of passive sampling devices for monitoring and compliance checking of POP concentrations in water. Environ Sci Pollut Res 2012;19:1885-1895.

Loos, R. et al. EU-wide survey of polar organic persistent pollutants in European river waters. Envrionmental Pollution 2009;157:561-568.

Malaj E, von der Ohe P, Grote M, Kühne R, Mondy CP, et al. Organic chemicals jeopardize the health of freshwater ecosystems on the continental scale. Procc Nat Acad Sci USA 2014;111:9549-9554.

Meland S, Farmen E, Heier LS, Rosseland BO, Salbu B, Tollefsen KE. Hepatic gene expression profile in brown trout (Salmo trutta) exposed to traffic related contaminants. Sci Total Environ 2011;409:1430-1443.

Moschet C, Wittmer I, Simovic J, Junghans M, Piazzoli A, Singer H, Stamm C, Leu C, Hollender J. How a complete persticide screening changes the assessment of surface water quality. Environ Sci Technol 2014;48:5423-5432.

Moschet C, Vermeirssen E, Seiz R, Pfefferli H, Hollender J. Picogram per liter detections of pyrethroids and organophosphates in surface waters using passive sampling. Water Research 2014;66:411-422.

Muñoz I, López - Doval JC, Ricart M, Villagrasa M, Brix R, et al. Bridging levels of pharmaceuticals in river water with biological community structure in the Llobregat river basin (northeast Spain). Environ Toxicol Chem 2009;28: 2706-2714.

Navarro-Ortega A, Acuña V, Batalla RJ, Blasco J, Conde C, et al. Assessing and forecasting the impacts of global change on Mediterranean rivers. The SCARCE Consolider project on Iberian basins. Environ Sci Pollut Res 2012;19:918-933.

Navarro-Ortega A, et al. Managing the effects of multiple stressors on aquatic ecosystems under water scarcity. The GLOBAQUA project. Sci Tot Environ 2014;503-504:3-9.

Nestler $\mathrm{H}$, et al. Multiple-endpoint assay provides a detailed mechanistic view of responses to herbicide exposure in Chlamydomonas reinhardtii. Aquatic Toxicology 2012;110-111:214-224.

OECD - Guidance document on developing and assessing adverse outcome pathways. Series on Testing and Assessment. No. 184 JT03338300. Paris 2013.

Pesce S, Lissalde S, Lavieille D, Margoum C, Mazzella N, et al. Evaluation of single and joint toxic effects of diuron and its main metabolites on natural phototrophic biofilms using a pollution-induced community tolerance (PICT) approach. Aquatic Toxicology 2010;99:492-499.

Price PS, Han, X. Maximum cumulative ratio (MCR) as a tool for assessing the value of performing a cumulative risk assessment. International Journal of Environmental Research and Public Health 2011;8:2212-2225.

Price P, Han X, Junghans M, Kunz P, Watts C, Leverett D. An application of a decision tree for assessing effects from exposures to multiple substances to the assessment of human and ecological effects from combined exposures to chemicals observed in surface waters and waste water effluents. Environmental Sciences Europe 2012;24:1-13.

Reichenberg F, Mayer P. Two complementary sides of bioavailability: accessibility and chemical activity of organic contaminants in sediments and soils. Environ Toxicol Chem 2006;25:1239-45.

Reifferscheid G, Maes HM, Allner B, Badurova J, Belkin S, Bluhm K, Brauer F, Bressling J, Domeneghetti S, Elad T, Flueckiger-Isler S, Grummt HJ, Guertler R, Hecht A, Heringa MB, Hollert H, Huber S, Kramer M, Magdeburg A, Ratte HT, Sauerborn-Klobucar R, Sokolowski A, Soldan P, Smital T, Stalter D, Venier P, Ziemann C, Zipperle J, Buchinger S. International round-robin study on the Ames fluctuation test. Environmental and Molecular Mutagenesis 2012;53, 85-197.

Scheubert K, Hufsky F. Böcker S. Computational mass spectrometry for small molecules. Journal of Cheminformatics 2013;5:12. 
Schriks M, Heringa MB, van der Kooi MME, de Voogt P, van Wezel AP. Toxicological relevance of emerging contaminants for drinking water quality. Water Research 2010;44:461-476.

Schulze T, Krauss M, Hug C, Walz K, Brack W. On-site large volume solid phase extraction - how to get 1000 litres of water into the laboratory. Poster WE133 at SETAC Europe 2014

Schymanski EL, Bataineh M, Goss KU, Brack W. Integrated analytical and computer tools for structure elucidation in effect-directed analysis. TrAC Trends Anal Chem 2009;28:550-561.

Schymanski EL, Singer HP, Longrée P, Loos M, Ruff M, Straavs MA, Ripollés Vidal C, Hollender J. Strategies to characterize polar organic contamination in wastewater: Exploring the capability of high resolution mass spectrometry, Environ Sci Technol 2014,48:1811-1818.

Sébillot A, Damdimopoulou P, Ogino Y, Spirhanzlova P, Miyagawa S, Du Pasquier D, Mouatassim N, Iguchi T, Lemkine GF, Demeneix BA and Tindall AJ. Rapid fluorescent detection of (anti-)androgens with spiggin-GFP medaka. Environ Sci Technol 2014;48:10919-10928.

Segner H, Wenger M, Möller AM, Köllner B, Casanova-Nakayama A. Immunotoxic effects of environmental toxicants in fish - how to assess them ? Environmental Science and Pollution Research 2012;19:2465-2478.

Smedes F, Booij K. Guidelines for passive sampling of hydrophobic contaminants in water using silicone rubber samplers. ICES Tech Mar E Environ Sci 2012;52. Available from: http://info.ices.dk/pubs/times/times52/120621 TIMES 52 Final.pdf

Smedes F, van Vliet LA, Booij K. Multi-Ratio Equilibrium Passive Sampling Method to Estimate Accessible and Pore Water Concentrations of Polycyclic Aromatic Hydrocarbons and Polychlorinated Biphenyls in Sediment. Environ Sci Technol 2013,47: 510-517.

SOLUTIONS (http://www.solutions-project.eu/)

Su G, Yu H, Lam MH, Giesy JP, Zhang X. Mechanisms of Toxicity of Hydroxylated Polybrominated Diphenyl Ethers (HO-PBDEs) Determined by Toxicogenomic Analysis with a Live Cell Array Coupled with Mutagenesis in Escherichia coli. Environ Sci Technol 2014;48:5929-37.

Tang YYM, Busetti F, Charrois JWA, Escher BI. Which chemicals drive biological effects in wastewater and recycled water? Water Res 2014;60:289-299.

Ter Laak TL, Van der Aa M, Houtman CJ, Stoks PG, Van Wezel AP. Relating environmental concentrations of pharmaceuticals to consumption: A mass balance approach for the river Rhine. Environ Int 2010;36:403-409.

Thomas KV, Hurst MR, Matthiessen P, Waldock MJ. Characterization of estrogenic compounds in water samples collected from United Kingdom estuaries. Environ Toxicol Chem 2009;20:2165-2170.

Umbuzeiro GA, Machala M, Weiss J. Diagnostics tools for Effect Directed Analysis for mutagens, AhR agonists, and endocrine disruptors In: Brack W (ed) Effect-directed analysis of complex environmental contamination. Spring-Verlag, Heidelberg, p. 69-82. 2011.

Vadillo JM, Barceló D. Mass spectrometry: Fifth meeting of the Spanish Society of Mass Spectrometry (SEEM). Anal. Bioanal. Chem. 2012;402:2275-2276.

Van den Brink PJ, Alexander AC, Desrosiers M, Goedkoop W, Goethals PLM, et al. Traits-based approaches in bioassessment and ecological risk assessment: Strengths, weaknesses, opportunities and threats. Integrated environmental assessment and management 2011;7:198-208.

Van den Brink PJ, Baird DJ, Baveco JM, Focks A. The use of traits-based approaches and eco(toxico)logical models to advance the ecological risk assessment framework for chemicals. Integrated Environmental Assessment and Management 2013;9:e47-e57.

Vermeirssen ELM, Dietschweiler C, Escher BI, van der Voet J, Hollender J. Uptake and release kinetics of 22 polar organic chemicals in the Chemcatcher passive sampler. Anal Bioanal Chem 2013;405:5225-5236.

Vrana B. NORMAN Interlaboratory Study on passive sampling of emerging pollutants, Chemical Monitoring On Site (CM Onsite) organised by the NORMAN Association and European DG Joint Research Centre (JRC) in support of the Common Implementation Strategy (CIS) of the Water Framework Directive (WFD), NORMAN Network Bulletin, 3, 13, 2012.

Wang XJ, Hayes JD, Wolf CR. Generation of a stable antioxidant response element-driven reporter 
gene cell line and its use to show redox-dependent activation of Nrf2 by cancer chemotherapeutic agents. Cancer Research 2006;66:10983-10994.

Williams TD, Turan N, Diab AM, Wu H, Mackenzie C, Bartie KL, Hrydziuszko O, Lyons BP, Stentiford GD, Herbert JM, Abraham JK, Katsiadaki I, Leaver MJ, Taggart JB, George SG, Viant MR, Chipman KJ, Falciani F. Towards a System Level Understanding of Non-Model Organisms Sampled from the Environment: A Network Biology Approach. PLoS Comput Biol 2011;7(8):e1002126.

Wolf S, Schmidt S, Muller-Hannemann M, Neumann S. In silico fragmentation for computer assisted identification of metabolite mass spectra. Bmc Bioinformatics 2010;11.

Yang F, Huang W, Xie W, Lu C, Liu W. Targeted analytical toxicology: Simultaneous determination of $17 \alpha$-ethynylestradiol and the estrogen-induced vitellogenin biomarker. Environment International. 2015;74:119-124.

Yeh RYL, Farré MJ, Stalter D, Tang JYM, Molendijk J, Escher BI. Bioanalytical and Chemical Evaluation of Disinfection By-Products in Swimming Pool Water. Water Research 2014;59:172-184.

Zhang X, Wiseman S, Yu H, Liu H, Giesy JP, et al. Assessing the toxicity of naphthenic acids using a microbial genome wide live cell reporter array system. Environmental Science and TechnologyColumbus 2011;45:1984.

Zonja B, Aceña J, Petrovic M, Pérez S, Barceló D. Transformation Products of Emerging Contaminants: Analytical challenges and Future needs. In Dimitra A. Lambropoulou and Leo M. L. Nollet, editors: Transformation Products of Emerging Contaminants in the Environment: Analysis, Processes, Occurrence, Effects and Risks. JohnWiley \& Sons, Ltd., pp. 303-324. 2014. 
Table 1: $\quad$ Environmental Quality Standard (EQS), annual average (AA) and maximum allowable concentrations (MAC) set for the newly established WFD priority substances in inland and other surface waters* (EU Dir. 2013/39/EU). Unit: $\mu \mathrm{g} / \mathrm{l}$, nomenclature as in the legal reference

\begin{tabular}{|l|c|c|c|c|}
\hline & $\begin{array}{c}\text { AA-EQS } \\
\text { Inland surface } \\
\text { waters }\end{array}$ & $\begin{array}{c}\text { AA-EQS } \\
\text { Other } \\
\text { surface } \\
\text { waters }\end{array}$ & $\begin{array}{c}\text { MAC-EQS } \\
\text { Inland } \\
\text { surface } \\
\text { waters }\end{array}$ & $\begin{array}{c}\text { MAC-EQS } \\
\text { Other } \\
\text { surface } \\
\text { waters }\end{array}$ \\
\hline Dicofol & $1.3 \times 10^{-3}$ & $3.2 \times 10^{-5}$ & - & - \\
\hline $\begin{array}{l}\text { Perfluorooctane sulfonic acid } \\
\text { and its derivatives (PFOS) }\end{array}$ & $6.5 \times 10^{-4}$ & $1.3 \times 10^{-4}$ & 36 & 7.2 \\
\hline Quinoxyfen & 0.15 & 0.015 & 2.7 & 0.54 \\
\hline Aclonifen & 0.12 & 0.012 & 0.12 & 0.012 \\
\hline Bifenox & 0.012 & 0.0012 & 0.04 & 0.004 \\
\hline Cybutryne (Irgarol) & 0.0025 & 0.0025 & 0.016 & 0.016 \\
\hline Cypermethrin & $6 \times 10^{-5}$ & $8 \times 10^{-6}$ & $6 \times 10^{-4}$ & $6 \times 10^{-5}$ \\
\hline Dichlorvos & 0.0016 & 0.0008 & 0.5 & $7 \times 10^{-5}$ \\
\hline $\begin{array}{l}\text { Hexabromocyclododecane } \\
\text { (HBCDD) }\end{array}$ & $2 \times 10^{-7}$ & $1 \times 10^{-8}$ & $3 \times 10^{-4}$ & $3 \times 10^{-5}$ \\
\hline $\begin{array}{l}\text { Heptachlor and heptachlor } \\
\text { epoxide }\end{array}$ & 0.065 & 0.0065 & 0.34 & 0.034 \\
\hline Terbutryn & & & $7 \times 10^{-4}$ & 7.05 \\
\hline
\end{tabular}

* Inland surface waters encompass rivers and lakes and related artificial or heavily modified water bodies. 
Table 2: Chemical analytical problems addressed in the SOLUTIONS project to support priority mixture identification

\begin{tabular}{|c|c|c|c|c|}
\hline Problem & Approach & Method & Aim & References \\
\hline \multirow[t]{4}{*}{$\begin{array}{l}\text { Compound detection } \\
\text { below EQS and } \\
\text { estimation of time- } \\
\text { averaged } \\
\text { concentrations }\end{array}$} & $\begin{array}{l}\text { Enrichment of trace compounds by time- } \\
\text { integrative passive sampling }\end{array}$ & $\begin{array}{l}\text { Partitioning and } \\
\text { adsorption based } \\
\text { passive sampling; } \\
\text { Flow controlled } \\
\text { passive sampling }\end{array}$ & $\begin{array}{l}\text { Widen applicability of passive } \\
\text { sampling by extending the method } \\
\text { domain on emerging compounds and } \\
\text { improve their performance in terms } \\
\text { of limits of quantification and } \\
\text { measurement uncertainty }\end{array}$ & $\begin{array}{l}\text { Lohmann et al. 2012, } \\
\text { Smedes and Booij } \\
\text { 2012, } \\
\text { Vrana 2012, } \\
\text { Vermeirssen et al., } \\
\text { 2013, Moschet et al., } \\
2014\end{array}$ \\
\hline & $\begin{array}{l}\text { Time-integrated sampling by in situ large } \\
\text { volume solid phase extraction }\end{array}$ & $\begin{array}{l}\text { Large-volume sampler } \\
\text { for application in situ } \\
\text { (e.g. at point sources } \\
\text { or on monitoring } \\
\text { ships) }\end{array}$ & $\begin{array}{l}\text { Development of routinely applicable } \\
\text { and commercially available } \\
\text { technique with negligible compound } \\
\text {-dependence of extraction efficiency; } \\
\text { applicable for chemical and } \\
\text { biotesting in parallel }\end{array}$ & Schulze et al. 2014 \\
\hline & $\begin{array}{l}\text { Hydrodynamic counter current } \\
\text { chromatography (HPCCC) }\end{array}$ & $\begin{array}{l}\text { HPCCC-liquid-liquid } \\
\text { partitioning }\end{array}$ & $\begin{array}{l}\text { Improved enrichment and clean up as } \\
\text { method improvements for wider use }\end{array}$ & Ignatova et al 2011 \\
\hline & $\begin{array}{l}\text { On-line extraction and clean up methodology } \\
\text { for LC }\end{array}$ & $\begin{array}{l}\text { Turbulent flow } \\
\text { chromatography }\end{array}$ & $\begin{array}{l}\text { Automated on-line enrichment } \\
\text { technique and clean up }\end{array}$ & $\begin{array}{l}\text { Lopez-Serna et al. } \\
2012\end{array}$ \\
\hline \multirow[t]{2}{*}{$\begin{array}{l}\text { Inadequate coverage } \\
\text { of environmental } \\
\text { mixture components }\end{array}$} & $\begin{array}{l}\text { Automated workflows for sensitive, } \\
\text { informative and routinely applicable target and } \\
\text { non-target screening techniques }\end{array}$ & $\begin{array}{l}\text { GC- and LC-HR } \\
\text { MS/MS techniques } \\
\text { with innovative } \\
\text { software tools and } \\
\text { parameter prediction }\end{array}$ & $\begin{array}{l}\text { Detection, identification and semi- } \\
\text { quantification of larger numbers of } \\
\text { chemicals at the same time including } \\
\text { unknowns }\end{array}$ & $\begin{array}{l}\text { Schriks et al. 2010, } \\
\text { Vadillo and Barceló } \\
\text { 2012, Schymanski et } \\
\text { al 2014, Krauss et al., } \\
2010\end{array}$ \\
\hline & $\begin{array}{l}\text { Structure elucidation procedures for } \\
\text { environmental trace contaminants and } \\
\text { transformation products by systematic } \\
\text { integration of analytical information from GC- }\end{array}$ & $\begin{array}{l}\text { Workflow integrating } \\
\text { analytical techniques } \\
\text { and the use of } \\
\text { innovative databases }\end{array}$ & $\begin{array}{l}\text { Identification of new chemicals } \\
\text { including transformation products } \\
\text { and other unknowns in various } \\
\text { matrices }\end{array}$ & $\begin{array}{l}\text { Zonja et al 2014, } \\
\text { Huntscha et al., 2014, } \\
\text { Schymanski et al } \\
\text { 2014, Gerlich and }\end{array}$ \\
\hline
\end{tabular}


and LC-HRMS/MS with, prediction tools for retention, MS fragmentation, hydrogen-

deuterium exchange and mass spectral and compound databases

Total contaminant concentrations in sediment do not reflect the exposure, i.e. biologically accessible

concentration,

because of unknown uptake capacity of sediments

\section{Detection and} unraveling of

internal contamination of

biota with trace

contaminants Availability-based approach for the assessment of sediment contamination using equilibrium partitioning passive sampling ; both nondepletive (chemical activity) and depletive (accessible)

\section{In tissue passive sampling to assess internal} exposure to environmental mixture

nts and

Parallel detection of multiple contaminants and selected biomarkers

Improved sample clean-up

for determination of biota concentrations and software in a consensus lines of evidence approach

Neumann 2013, Hug

et al., 2014

A release isotherm is

recorded by

equilibrations at

different sampler -

sediment ratios

providing both the

level in pore water and

the accessible

concentration.

\section{Silicone thin-films as}

'chemometers'

equilibrated in intact

tissues

LC-MS/MS screening

approaches for

contaminants and

marker proteins

Selective extraction and clean-up for lipid removal
Obtaining measured concentrations from sediment samples that allow spatial comparison and conversion into units applicable in other matrices (water, lipid) for comparison between environmental compartments.

\section{Reichenberg and}

Mayer 2006
Smedes et al., 2013 
Table 3: Bioanalytical tools used in the SOLUTIONS project to improve the impact assessment of mixtures for diagnostic, forensic and ecological quality purposes

\begin{tabular}{|c|c|c|c|c|c|}
\hline $\begin{array}{l}\text { Biological } \\
\text { level }\end{array}$ & Biosystem & $\begin{array}{l}\text { Response } \\
\text { observation }\end{array}$ & $\begin{array}{l}\text { Indication } \\
\text { of }\end{array}$ & $\begin{array}{l}\text { Project } \\
\text { aim }\end{array}$ & $\begin{array}{l}\text { Method } \\
\text { reference }\end{array}$ \\
\hline \multirow[t]{7}{*}{ Key events } & \multirow[t]{2}{*}{ Feral fish } & $\begin{array}{l}\text { EROD activity, } \\
\text { bile PAH } \\
\text { metabolites }\end{array}$ & $\begin{array}{l}\text { internal } \\
\text { exposure }\end{array}$ & \multirow[t]{2}{*}{$\begin{array}{l}\text { in situ } \\
\text { exposure }\end{array}$} & $\begin{array}{l}\text { Brinkmann et } \\
\text { al. } 2013\end{array}$ \\
\hline & & GST activity & $\begin{array}{l}\text { internal } \\
\text { exposure }\end{array}$ & & $\begin{array}{l}\text { Kammann et } \\
\text { al. } 2014\end{array}$ \\
\hline & \multirow[t]{2}{*}{$\begin{array}{l}\text { Mammalian } \\
\text { and Fish cells }\end{array}$} & EROD activity & dioxin-like & \multirow[t]{4}{*}{ EDA detector } & $\begin{array}{l}\text { Creusot et al. } \\
2013 a\end{array}$ \\
\hline & & $\begin{array}{l}\text { nuclear } \\
\text { receptor } \\
\text { activation } \\
\text { /inhibition }\end{array}$ & $\begin{array}{l}\text { estrogen/ } \\
\text { anti-estrogen }\end{array}$ & & $\begin{array}{l}\text { Creusot et al. } \\
\text { 2013b }\end{array}$ \\
\hline & $\begin{array}{l}\text { Mammalian } \\
\text { and Yeast cells }\end{array}$ & $\begin{array}{l}\text { nuclear } \\
\text { receptor } \\
\text { activation } \\
\text { /inhibition }\end{array}$ & $\begin{array}{l}\text { androgen/ } \\
\text { anti-androgen }\end{array}$ & & $\begin{array}{l}\text { Jalova et al. } \\
2013\end{array}$ \\
\hline & $\begin{array}{l}\text { Mammalian } \\
\text { cells }\end{array}$ & $\begin{array}{l}\text { fish nuclear } \\
\text { receptor } \\
\text { inhibition }\end{array}$ & $\begin{array}{l}\text { corticosteroid/ } \\
\text { anti-corticoid }\end{array}$ & & $\begin{array}{l}\text { Kugathas and } \\
\text { Sumpter } \\
2011\end{array}$ \\
\hline & $\begin{array}{l}\text { Isolated } \\
\text { enzyme }\end{array}$ & $\begin{array}{l}\text { acetylcholine- } \\
\text { esterase } \\
\text { activity }\end{array}$ & neurotoxicity & EDA detector & $\begin{array}{l}\text { Holth and } \\
\text { Tollefsen } \\
2012\end{array}$ \\
\hline \multirow[t]{4}{*}{$\begin{array}{l}\text { Cellular } \\
\text { responses }\end{array}$} & $\begin{array}{l}\text { E. coli, } \\
\text { yeast }\end{array}$ & $\begin{array}{l}\text { gene } \\
\text { expression, } \\
\text { alterations on } \\
\text { proliferation of } \\
\text { gene }\end{array}$ & $\begin{array}{l}\text { stress-response } \\
\text { activation }\end{array}$ & EDA detector & $\begin{array}{l}\text { Zhang et al. } \\
\text { 2011, } \\
\text { Su et al., } \\
2014\end{array}$ \\
\hline & $\begin{array}{l}\text { Salmonella } \\
\text { typhimurium }\end{array}$ & $\begin{array}{l}\text { Ames test } \\
\text { using } \\
\text { diagnostic } \\
\text { strains }\end{array}$ & mutagenicity & EDA detector & $\begin{array}{l}\text { Umbuzeiro et } \\
\text { al. 2011, } \\
\text { Reiferscheid } \\
\text { et al. } 2012\end{array}$ \\
\hline & \multirow[t]{2}{*}{$\begin{array}{l}\text { Mammalian } \\
\text { cell line }\end{array}$} & $\begin{array}{l}\text { Nrf2 protein in } \\
\text { AREc32 } \\
\text { activation }\end{array}$ & oxidative stress & \multirow[t]{2}{*}{$\begin{array}{l}\text { adaptive } \\
\text { stress } \\
\text { response }\end{array}$} & $\begin{array}{l}\text { Knight et al. } \\
\text { 2009, Yeh et } \\
\text { al. } 2014 \\
\text { Wang et al. } \\
\text { 2006, Escher } \\
\text { et al. } 2012\end{array}$ \\
\hline & & $\begin{array}{l}\text { NF-kappaB } \\
\text { activation }\end{array}$ & $\begin{array}{l}\text { inflammation } \\
\text { as immune } \\
\text { response }\end{array}$ & & $\begin{array}{l}\text { Knight et al } \\
2009\end{array}$ \\
\hline
\end{tabular}




\begin{tabular}{|c|c|c|c|c|c|}
\hline & Fish cells & $\begin{array}{l}\text { Immune gene } \\
\text { modulation }\end{array}$ & $\begin{array}{l}\text { immune- } \\
\text { competence }\end{array}$ & & $\begin{array}{l}\text { Segner et al. } \\
2012\end{array}$ \\
\hline \multirow[t]{9}{*}{$\begin{array}{l}\text { Organism } \\
\text { responses }\end{array}$} & $\begin{array}{l}\text { Zebrafish } \\
\text { embryo }\end{array}$ & $\begin{array}{l}\text { estrogenic cyp } \\
\text { 19a1b-GFP } \\
\text { activation }\end{array}$ & $\begin{array}{l}\text { estrogen/anti- } \\
\text { estrogen }\end{array}$ & $\begin{array}{l}\text { validation of } \\
\text { cellular } \\
\text { response } \\
\text { indication; } \\
\text { EDA detector }\end{array}$ & $\begin{array}{l}\text { Brion at al. } \\
\text { 2012, Fetter } \\
\text { et al. } 2014\end{array}$ \\
\hline & \multirow[t]{2}{*}{$\begin{array}{l}\text { Medaka } \\
\text { embryo }\end{array}$} & $\begin{array}{l}\text { estrogenic } \\
\text { choriogenin- } \\
\text { GFP activation }\end{array}$ & $\begin{array}{l}\text { estrogen/ anti- } \\
\text { estrogen }\end{array}$ & & $\begin{array}{l}\text { Kurauchi et } \\
\text { al. } 2005\end{array}$ \\
\hline & & $\begin{array}{l}\text { androgenic } \\
\text { spiggin-GFP } \\
\text { activation }\end{array}$ & $\begin{array}{l}\text { androgen/ anti- } \\
\text { androgen }\end{array}$ & & $\begin{array}{l}\text { Sébillot et al. } \\
2014\end{array}$ \\
\hline & $\begin{array}{l}\text { Xenopus } \\
\text { embryo }\end{array}$ & $\begin{array}{l}\text { thyroid } \\
\text { THbZIP-gfp } \\
\text { activation }\end{array}$ & $\begin{array}{l}\text { thyroid/ anti- } \\
\text { thyroid }\end{array}$ & EDA detector & $\begin{array}{l}\text { Fini et al. } \\
2007\end{array}$ \\
\hline & Algae & $\begin{array}{l}\text { growth, } \\
\text { transcriptome }\end{array}$ & $\begin{array}{l}\text { apical effects, } \\
\text { MOA }\end{array}$ & $\begin{array}{l}\text { effect } \\
\text { diagnostics }\end{array}$ & $\begin{array}{l}\text { Nestler et al. } \\
2012\end{array}$ \\
\hline & Daphnids & $\begin{array}{l}\text { motility, } \\
\text { transcriptome, } \\
\text { metabolome }\end{array}$ & $\begin{array}{l}\text { apical effects, } \\
\text { MOA }\end{array}$ & & $\begin{array}{l}\text { Meland et al. } \\
\text { 2011, } \\
\text { Williams et } \\
\text { al. } 2011\end{array}$ \\
\hline & \multirow[t]{2}{*}{$\begin{array}{l}\text { Zebrafish } \\
\text { embryo }\end{array}$} & $\begin{array}{l}\text { development, } \\
\text { transcriptome }\end{array}$ & $\begin{array}{l}\text { apical effects, } \\
\text { MOA }\end{array}$ & & $\begin{array}{l}\text { Büttner et al. } \\
\text { 2012, Klüver } \\
\text { et al. } 2011\end{array}$ \\
\hline & & $\begin{array}{l}\text { thyroid } \\
\text { disruption }\end{array}$ & $\begin{array}{l}\text { endocrine } \\
\text { activity }\end{array}$ & & $\begin{array}{l}\text { Schmitt et al. } \\
2012\end{array}$ \\
\hline & $\begin{array}{l}\text { Abramis } \\
\text { abramis }\end{array}$ & histopathology & organ toxicity & & $\begin{array}{l}\text { Wolf et al. } \\
2010\end{array}$ \\
\hline \multirow[t]{2}{*}{$\begin{array}{l}\text { Community } \\
\text { responses }\end{array}$} & Algal biofilms & $\begin{array}{l}\text { community } \\
\text { tolerance } \\
\text { measured as } \\
{ }^{14} \mathrm{C} \text {-uptake and } \\
\text { biofilm } \\
\text { formation } \\
\text { kinetics }\end{array}$ & $\begin{array}{l}\text { ecological } \\
\text { mode-of-action }\end{array}$ & in situ effects & $\begin{array}{l}\text { Blanck 2002, } \\
\text { Pesce et al. } \\
2010\end{array}$ \\
\hline & Invertebrates & $\begin{array}{l}\text { alterations of } \\
\text { trait } \\
\text { composition }\end{array}$ & $\begin{array}{l}\text { ecological } \\
\text { mode-of-action }\end{array}$ & & $\begin{array}{l}\text { Van den } \\
\text { Brink et al. } \\
2011\end{array}$ \\
\hline
\end{tabular}

EDA - effect-directed analysis

MOA - mode-of-action 
Figure captions

Fig. 1: Challenges to deal with mixtures of pollutants in water quality monitoring and to provide management solutions

Fig 2: Heatmap of concentrations for 141 chemicals reported in Moschet et al. (2014) in five rivers, clustered to identify occurring mixture patterns. MDL=minimum detection limit

Fig 3: Conceptual framework for bioanalytical tools illustrating their place in an adverse outcome pathway network elucidated by mixture exposure and indicating the potential roles of bioanalytical tools in mixture impact assessment

Fig 4: $\quad$ Principles of a tiered effect-directed analysis (EDA) 
Fig 1

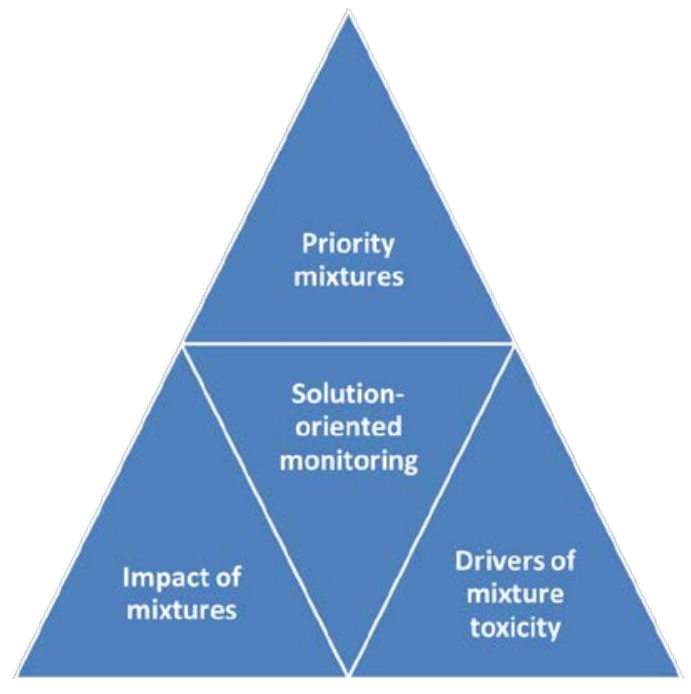


Chemical concentrations (ng/l) in 5 rivers (Moschet et al. 2014)

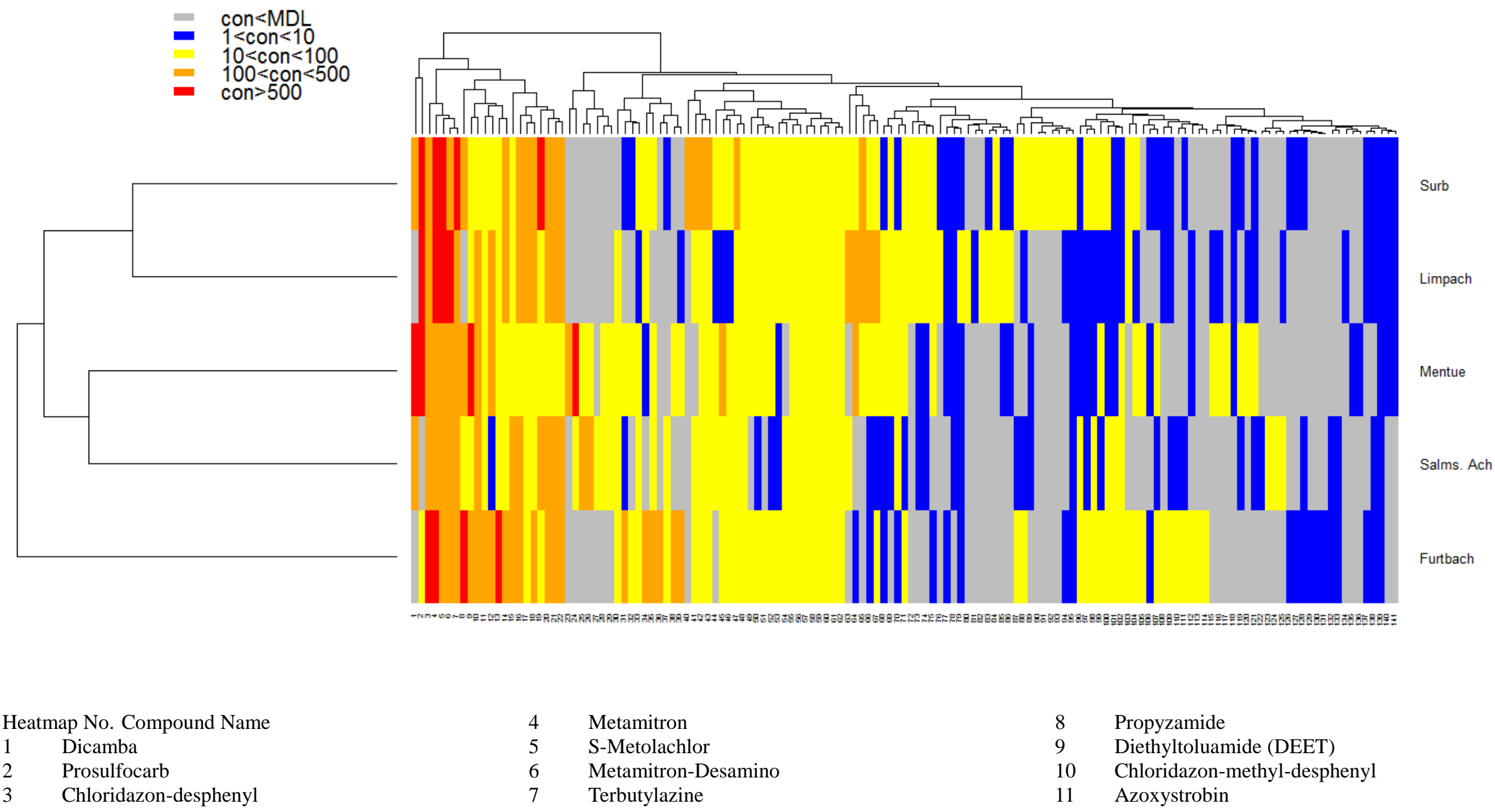


Propamocarb

Metazachlor-ESA

Isoproturon

Metalaxyl-M

Metolachlor-OXA

Flufenacet

Ethofumesate

Chloridazon

Metolachlor-ESA

2-methyl-4-chlorophenoxyacetic acid

(MCPA)

22 Mecoprop-P

23 Asulam

24 5-Chloro-2-methyl-4-isothiazolin-3-on (CMI)

Piperonyl butoxide

Carbetamide

$\mathrm{N}$-(2,4-Dimethylphenyl)formamide

Diuron-desmonomethyl (DCPMU)

Simazine

Carbofuran

Metazachlor

Napropamide

Pethoxamid

Cycloxydim

Linuron

Propachlor-OXA

Pyrimethanil

Propachlor-ESA

Propachlor

Trinexapac acid

Cyprodinil

Azoxystrobin free acid

Atrazine

Foramsulfuron

N,N-Dimethyl-N'-phenylsulphamide (DMSA)

Dimethomorph

Sulcotrione

2,4-dichlorophenoxyacetic acid

Pymetrozine
Fluazifop free acid

Propiconazole

Tebuconazole

Diazinon

Mesotrione

Atrazine-2-Hydroxy

Desethylatrazine

2,6-Dichlorobenzamide

Diuron

Nicosulfuron

Desethylterbuthylazine

Acetochlor-, Alachlor-OXA

Carbendazim

4-(4-chloro-2-methylphenoxy)butanoic acid

(MCPB)

64 Pencycuron

65 Lenacil

Metribuzin

Cyproconazole

Prothioconazole desethio

Metribuzin-Desamino (DA)

Ioxyni

Flufenacet-ESA

Fluroxypyr

Tembotrione

Thiacloprid

Epoxiconazole

Pyraclostrobin

Mesosulfuron-methyl

Thiacloprid_amide

Dimethenamid

Metrafenone

Dimethe mid-OXA

Kresoxim-methyl

Fenpropimorph

Dimethenamid-ESA

Spiroxamine

Bromoxynil

Fenhexamid
Boscalid

Imazamox

Difenoconazole

Flusilazole

Iprovalicarb

Metosulam

Fenpropidin

Fipronil

Thiamethoxam

Pirimicarb

Terbutylazine-2-hydroxy

Atrazine-desethyl-2-hydroxy

00 Terbutylazin-desethyl-2-hydroxy

101 Bifenox Acid

Dimethoate

Dimethachlor ESA

Fenamidone

Fludioxonil

Imidacloprid

3,5-dibromo-4-hydroxybenzoeacid

Isoproturon-monodemethyl

Metolachlor-Morpholinon

Tebufenozide

Terbutryn

Mandipropamid

Methomyl

Imidacloprid desnitro

Mefenpyr-Diethyl

Chlorotoluron

Benthiavalicarb-isopropyl

Monolinuron

Trifloxystrobin

Fluoxastrobin

Triflusulfuron methyl

Methoxyfenozid

Cyromazine

Dichlorprop

Myclobutanil

Mepanipyrim 
127 3-Phenoxybenzoic acid

128 Oryzalin

129 Irgarol-descyclopropyl

130 Clothianidin

131 Chlorfenvinphos
132 Terbacil

133 Simazine-2-hydroxy

Methiocarb

Dimefuron

Thifensulfuron methyl
137 Acetochlor-, Alachlor-ESA

138 Dimethachlor

139 Tepraloxydim

140 Amidosulfuron

141 Clomazone 
Fig 3

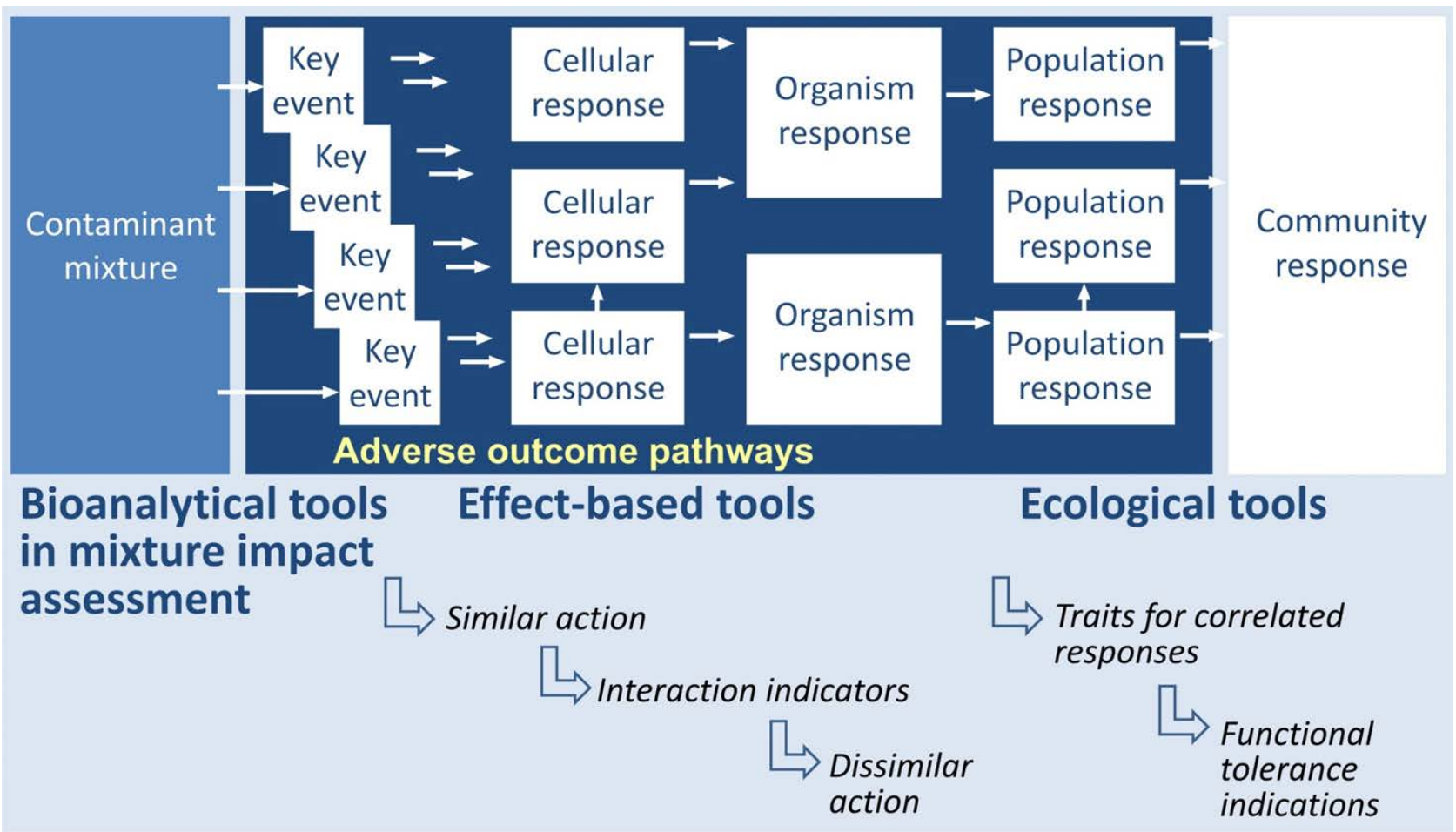


Fig 4

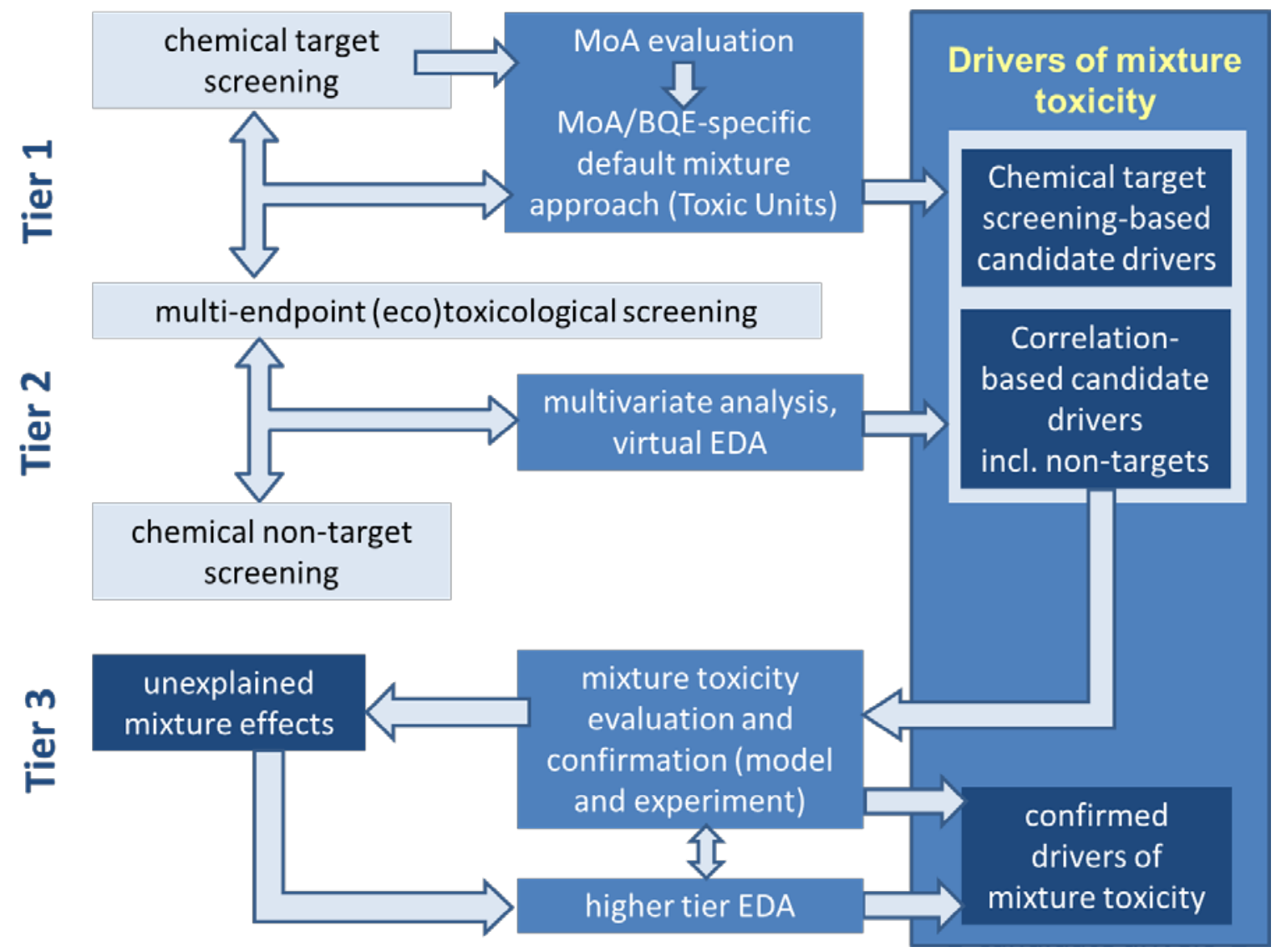

